\title{
The Government's Strategy to Promote the Export of MSME Products during the Covid-19 Pandemic
}

\author{
Dedi Triharjanto ${ }^{1}$, Cicih Ratnasih ${ }^{2}$, Yolanda $^{3}$ \\ \{dtriharjanto@yahoo.com ${ }^{1}$, cicih_ratnasih@borobudur.ac.id ${ }^{2}$, yolanda@borobudur.ac.id ${ }^{3}$ \} \\ Universitas Borobudur, Jakarta, Indonesia ${ }^{1,2,3}$
}

\begin{abstract}
The objective of this exploration is to check out the effect of the rupiah's conversion standard versus the US dollar, the quantity of MSMEs developing, speculation, banking credit, and expansion on MSME item trades, as well as the implications for per capita income and employment in the MSME sector. Multiple Linear Regression using the Ordinary Least Square Approach was employed as the research technique in this study. The research variables used in this study were the rupiah conversion scale against the US dollar, the development of the quantity of MSMEs, venture, banking credit, and expansion, all of which served as independent variables affecting the export of MSME products, which served as the dependent variable, as well as per capita income and employment in the SMEs sector. The findings revealed that (1) the rupiah's exchange rate against the US dollar, the number of MSMEs growing, investment, banking credit, and inflation all had a significant impact on MSME product exports, and (2) the rupiah's exchange rate against the US dollar had a significant and positive impact on MSME product exports.
\end{abstract}

Keywords: Strategy; Promote; Export; MSME Product; Pandemic

\section{Introduction}

Micro, small, and medium-sized businesses assume a basic and key part in public financial turn of events, especially as far as job creation and growth. MSMEs are very important in disseminating the benefits of improvement. MSMEs have also demonstrated to be unaffected by the economic downturn. Only MSMEs were able to stay afloat when the crisis struck in 1997-1998. This experience has prompted various parties, particularly the government and legislature, to allocate a larger share of resources to micro, small, and medium-sized firms. With the enactment of Law No. 20 of 2008, he demonstrates his care for MSMEs.

According to Tambunan (2015:15), A company is classified as a Micro Business in the event that it has a greatest resource of Rp 50 million and a most extreme yearly turnover of Rp 300 million, or around Rp 1,000,000 every day (accepting dynamic activity for 300 days out of each year); the furthest reaches of turnover for Small Businesses is around Rp. 8.3 million every day; and the maximum furthest reaches of turnover for Medium Enterprises is around Rp. 167 million every day [1]. By referring to the MSME criteria above, we can now evaluate whether the business we are running falls into the micro, small, or medium scale business category. The original asset worth (barring area and structures), the normal yearly turnover, or 
the quantity of super durable staff are utilized to order Micro Enterprises (UMi), Small Enterprises (UK), Medium Enterprises (UM), and Large Enterprises (UB). In the interim, as indicated by Aufar (2014:8), the Ministry of Cooperatives and MSMEs characterizes MSMEs as follows: Small Businesses (UK), including Micro Enterprises (UMI), are business substances with yearly deals of at minimum Rp. 1,000,000,000 and a net worth of at minimum Rp. 200,000,000, barring area and structures for organization premises. In the interim, Medium Enterprises (ME) are organizations held by Indonesian individuals with a total assets of between Rp. 200 million and Rp. 10 million, barring area and designs [2].

As for the current digital era, the creations of MSMEs are increasing because they do not require a store and only market their products online; and haven't obtained a company license yet. According to the most recent data from the Indonesian Ministry of Cooperatives and SMEs, MSMEs will account for around 99.99 percent (70.93 million units) of all business actors in Indonesia in 2020, while micro-enterprises will account for 98.67 percent of all business units and medium-sized enterprises will account for 0.10 percent. The magnitude of MSME economic activity accounts for almost $60 \%$ of Indonesia's overall Gross Domestic Product. Indonesia's GDP was about Rp. 13600 trillion in 2017. As a result, MSMEs' total revenue is estimated to be roughly Rp. 8160 trillion. Microbusinesses contribute around IDR 5000 trillion each year, small businesses approximately IDR 1300 trillion, medium businesses approximately IDR 1800 trillion, and large businesses approximately Rp 5400 trillion.

The structure of Indonesian MSMEs is dominated by Micro Enterprises. It can be seen from table $1.3,98.7 \%$ of this structure has not changed from 10 years ago. This condition indicates that our Micro Enterprises have not been upgraded to become Small or Medium Enterprises. Compared with developed countries, the balance of business units is $99.8 \%$, Micro Enterprises account for 93 percent of all businesses in the European Union. It demonstrates that while the differences are minor, the structure of MSMEs in more industrialized nations is sound. According to data from the Ministry of Cooperatives, Indonesia's MSMEs are made up of 63.3 million people, accounting for 98 percent of the country's micro-businesses. Small businesses are 783 thousand or 1.28 percent, and medium businesses are only 60 thousand or 0.09 percent.

In relation to efforts to encourage MSMEs to go international, MSMEs products must have enormous potential to be able to penetrate the export market. By exporting, MSMEs have the potential to gain greater profits, because the market will become extensive. However, there are still many who do not know and understand the procedures and mechanisms that must be followed so that their products can be exported abroad. According to Kemenkop SME data in December 2019, the contribution record of MSME products to total exports is at 14.5 percent. It shows that the condition of Indonesian MSMEs is still low, and this should be of great concern. According to statistics from the Ministry of Cooperatives, the coronavirus pandemic has afflicted 1,785 cooperatives and 163,713 Micro, Small, and Medium Enterprises (MSMEs). (Mei 2020, Antara). Food and beverage is the MSME industry that has been hit the worst. Cooperatives involved in services and production, according to the Ministry of Cooperatives and MSMEs, were likewise the most hit by the COVID-19 epidemic. MSME enterprises are affected by a drop in sales, a lack of finance, and a lack of distribution. During the large-scale social restrictions (PSBB) imposed by COVID-19, at least $39.9 \%$ of MSMEs elected to cut their stock of goods. Meanwhile, owing to the closure of physical storefronts, $16.1 \%$ of MSMEs elected to cut their workforce (Kemenkop, 2020). This study will explore the government's efforts to support export businesses for MSMEs and their strategies in dealing with the current pandemic. 


\section{Methodology}

A quantitative technique is used in this research. Quantitative data is information that can be quantified and is presented in the form of numbers. Secondary data was employed in this study, namely data in the form of quarterly/quarterly reports prepared and released by connected parties. Secondary data is required for this project, which will be collected in the form of time series data during an 11-year period, from 2010 to 2020. Additionally, researchers gathered secondary data from the Central Statistics Agency in Jakarta, the Ministry of Cooperatives and SMEs, Bank Indonesia, the Ministry of Trade, the Ministry of Industry, and the Ministry of Manpower and Transmigration. Explanatory research analysis or hypothesis research via explanation is the research design employed. Explanatory research is an analytical approach that uses hypothesis testing to understand the causal link between variables. According to Bungin (2013, p. 51), the explanatory format is used to express a generalization or explain the link between two variables; hence, explanatory research employs hypothesis testing and inferential statistics (for hypothesis testing). Through direct observation or online data, the analysis contains a causal link based on theories, literature works, journals, and past investigations.

\section{Results and Discussion}

Many variables have a role in supporting the export of MSME products. One of them is the rupiah's exchange rate versus the US dollar. The rate of change, often known as the exchange rate, is a measure of how much (foreign exchange rate), according to Yoopi Abhimanyu (2014, p. 35), is the price of a nation's currency relative to other countries' currencies. Another definition of the exchange rate written by Olivier Blanchard (2016, p. 16) in his book Macroeconomics is "The price of the home currency in terms of foreign currency is known as the nominal exchange rate." "An exchange rate is defined as the amount of one currency that may exchange per unit of another currency or the price of one currency in terms of another currency," Frank J. Fabozzi and Franco Modigliani (2012, p. 65) write. The supply and demand sides of the two currencies define the equilibrium point since this exchange rate involves two currencies.

The movement of the rupiah exchange rate in recent years has made all parties anxious. Many factors underlie this assessment. When talking about the monetary crisis 22 years ago, the resilience of the MSME sector is still remembered. When other sectors fall, but it is not the MSME sector. The Center for Information Development Studies (CIDES) notes that three factors make the section can survive. The three are closely related to each other. The fast proliferation of COVID-19 in Indonesia has had a huge economic impact on the country. The rupiah currency rate versus the US\$ has been adjusted (weakened) by -12.4 percent year to date, because the epidemic lasted from March 2 to April 16, 2020. The rupiah depreciated by $30.9 \%$, the Covid-19 outbreak can cause widespread and prolonged panic, and a snowball effect occurs, where the attack on the US dollar is getting larger if it is not anticipated early. So, the impact could be worse than the financial crisis in 2008. The rupiah exchange rate is still fluctuating and tends to weaken. Economic growth is also expected to slow drastically, eroded by the spread of the impact of the virus to various sectors of the economy.

The majority of business actors prefer to reduce the size of their products. The option to increase the price was not taken for fear of eroding overall profits because consumers also put the brakes on their spending. In addition to MSMEs that produce products in the form of tofu 
and tempeh, the impact is also felt by other MSME actors who use a lot of imported raw materials. Strategy after strategy has to be done. It starts from maximizing local raw materials to business efficiency. It is not uncommon for temporary termination of employment (PHK) to be a bitter pill to swallow. If this is allowed, the unemployment rate and the problem of poverty will increase. At this point, the government's crucial role in supporting the MSME sector is as follows:

\subsection{The Government Maximizes the Role of Indonesian Export Education and Training (PPEI)}

Through various policies, the government must ensure that the MSME sector is not affected by the weakening of the rupiah. The first step is to maximize the potential of domestic exports. It is crucial considering that the weak exchange rate benefits export players, including SMEs. As a solution, the government can maximize the role of Indonesian Export Education and Training (PPEI) in the Ministry of Trade. The institution has contributed to boosting the performance of regional MSMEs from Central Java to North Sulawesi. MSME actors have received assistance to improve their performance. This training can be in the form of product innovation, the use of quality local raw materials, training to make attractive product packaging, and so on.

\subsection{Financial Tax Reduction}

The policy that has been taken by the government is to reduce the final tax for MSMEs. President Joko Widodo (Jokowi) decided to lower the tax rate to only $0.5 \%$. However, the effectiveness of the MSME final tax has not been tested. It is considering the policy was just launched two years ago. Therefore, the Directorate General of Taxes at the Ministry of Finance must intensify the policy dissemination to MSME actors.

\subsection{Provision of Credit for MSME Capital}

The potential development of MSMEs in Indonesia cannot be isolated from banking support in lending to MSME actors when it comes to the increase of the number of MSMEs. The provision of money or an equal claim based on an agreement or loan arrangement between a bank and another party that compels the borrower to return his debt after a set term with interest, according to Banking Law number 10 of 1998 [5]. In 2015, around 60 percent to 70 percent of the MSME sector lacked access to bank finance. Bank Indonesia has established regulations mandating banks to contribute 5 percent of credit/financing to MSMEs in 2015, 10 percent in 2016, 15 percent in 2017, and 20 percent by the end of 2018.

Rooted on Bank Indonesia Regulation No. 17/12/PBI/2015, June 25, 2015, regarding Amendments to Bank Indonesia Rules No. 14/22/PBI/2012, and PBI No. 14/22/PBI/2012, regarding the Lending or Funding by Banking Institutions and Advisory for the Growth of Micro, Small, and Medium Enterprises, with supporting provisions, which in the PBI are required to allot finance to MSMEs, progressively beginning from 5\% in 2015, MSME loans climbed 7.69 percent year over year in the fourth quarter of 2019, according to statistics from the Financial Services Authority (OJK), a slower rate than the previous year's 9.85 percent (YoY). MSME loans were remained more concentrated on the wholesale and retail trade sector (50.39 percent), although growth slowed to 5.43 percent (YoY) from 7.89 percent the year before, dragging down overall MSME loan growth. The manufacturing industry, on the 
other hand, which received the second-largest amount of credit (10.24 percent), increased by 7.99 percent (YoY) from the previous year's 6.28 percent (YoY).

\subsection{The issuance of the Employment Creation Act}

In 2019, to accelerate the development of Micro, Small and Medium Enterprises (MSMEs) in line with the issuance of the Employment Creation Law, the Financing Policy Committee for MSMEs chaired by the Coordinating Minister for the Economy decided to change the KUR policy to a more pro-populist one that came into effect on January 1, 2020, namely:

a. Interest Rate is reduced from $7 \%$ to $6 \%$ per annum;

b. The total KUR ceiling is increased from 140 trillion to 190 trillion in 2020 and will be gradually increased up to Rp. 325 trillion in 2024;

c. An increase in the Micro KUR ceiling from Rp. 25 million to Rp. 50 million per debtor.

d. Micro KUR (People's Business Credit) total cumulative cap for the commerce sector increased from Rp. 100 million to Rp. 200 million, while Micro KUR (People's Business Credit) is not restricted to the production sector.

The Authority's desire for banks to boost MSME loans is understandable. But on the other hand, it should also be realized that the essence of the banking business is trust services. As a result, banks are obliged to channel their credit by prioritizing the precautionary principle. Along with this, the government, through the Investment Coordinating Board (BKPM) will encourage enormous investments to partner with Micro, Small, and Medium Enterprises (MSMEs). The investment was expected to stimulate employment growth.

\section{Conclusion}

Based on the results of the research and discussion, it was found that the strategy taken by the government to develop exports of MSME products was to Maximize the Role of Indonesian Export Education and Training (PPEI), Reducing Financial Taxes, Providing Credit for MSME Capital, and issuing the Employment Creation Law. The rapid growth in the number of MSMEs needs to be accompanied by the immense support from the government given the great potential and contribution of the MSME sector to the Indonesian economy. The seriousness of the Indonesian government is paying attention to the MSME sector should be implemented in the policies contained in the assistance program, legal products related to MSMEs, and the establishment of institutions to handle MSMEs.

\section{References}

[1] Tambunan, T. T. H. (2012). Peluang, Tantangan dan Ancaman bagi UMKM Indonesia dalam Era CAFTA dan ME-ASEAN 2015. Prosiding Seminar \& Konferensi Nasional Manajemen Bisnis.

[2] Aufar. (2014). Definisi UMKM menurut Kementrian Koperasi dan UMKM dalam Aufar (2014:8). Skripsi.

[3] Tambunan, T. (2021). Micro, small and medium enterprises in times of crisis: Evidence from Indonesia. Journal of the International Council for Small Business. https://doi.org/10.1080/26437015.2021.1934754

[4] Abimanyu, Y. (2017). China Economic Development and its Impact on the Indonesian 
Economy. Kajian Ekonomi Dan Keuangan. https://doi.org/10.31685/kek.v1i1.273

[5] Kasmir. (2014). Laporan Keuangan Bank. Manajemen Perbankan.

[6] 2019 Dissertation List. (2020). PS: Political Science \& Politics. https://doi.org/10.1017/s1049096520000700

[7] Adam, P., Rosnawintang, Nusantara, A. W., \& Muthalib, A. A. (2017). A model of the dynamic of the relationship between exchange rate and Indonesia's export. International Journal of Economics and Financial Issues.

[8] Adi Kurnia, C. (2020). DAMPAK PANDEMI COVID-19 DAN PERUBAHAN POLA ADMINISTRASI TERHADAP PELAKU UMKM EKSPOR DAN IMPOR. AlIjtima $i$ : International Journal of Government and Social Science. https://doi.org/10.22373/jai.v6i1.607

[9] Adrian, A. (2019). EMPOWERMENT STRATEGIES OF MICRO, SMALL, MEDIUM ENTERPRISES (MSMEs) TO IMPROVE INDONESIA EXPORT PERFORMANCE. International Journal of Economics, Business and Accounting Research (IJEBAR). https://doi.org/10.29040/ijebar.v2i04.222

[10] Akalpler, E. (2013). Does Inflation Increase the Export? Case Study Turkey. Theoretical and Practical Research in Economic Fields.

[11] Aksin, N. (2018). UPAH DAN TENAGA KERJA (Hukum Ketenagakerjaan dalam Islam). Jurnal Meta Yuridis. https://doi.org/10.26877/m-y.v1i2.2916

[12] Alfiyani, N. (2020). Perbandingan Regulasi Ketenagakerjaan dalam Undang-Undang Ketengakerjaan dan Undang-Undang Cipta Kerja Nur Alfiyani. Jurnal Hukum Dan Kemasyarakatan.

[13] Amadeo, K. (2020). Inflation Targeting Definition and How It Works.

[14] Amri, A., \& Iskandar, I. (2021). KAUSALITAS KONSUMSI LISTRIK PER KAPTA DAN PDB PER KAPITA DI INDONESIA. Jurnal Ekonomi Dan Pembangunan. https://doi.org/10.22373/jep.v12i1.145

[15] Andrianto. (2020). Manajemen Kredit (Teori dan Konsep Bagi Bank Umum). Pasuruan: CV. Penerbit Qiara Media.

[16] Arianto, B. (2020). Pengembangan UMKM Digital di Masa Pandemi Covid-19. ATRABIS: Jurnal Administrasi Bisnis.

[17] Azzam, A., Suhendra, I., \& Setyadi, S. (2018). DAMPAK FAKTOR FUNDAMENTAL MAKROEKONOMI TERHADAP KURS PADA SISTEM NILAI TUKAR MENGAMBANG BEBAS DI TIGA NEGARA ASEAN. Jurnal EkonomiQu. https://doi.org/10.35448/jequ.v8i1.4939

[18] Babcock, J., Baldwin, C., Brackemyre, T. P., Chen, S. Y., El-Sabaawi, L. A., Galvez, C. C., ... Sivmons, Z. (2019). International trade. International Lawyer. https://doi.org/10.4337/9781788975803.00041

[19] Bahri, S. (2017). Perubahan dan Kesinambungan Kebijakan-Kebijakan Ekonomi Makro: Kasus Indonesia dan Malaysia Tahun 1997-1999. Jurnal Politik. https://doi.org/10.7454/jp.v2i2.79

[20] Bakker, A. B., \& de Vries, J. D. (2021). Job Demands-Resources theory and selfregulation: new explanations and remedies for job burnout. Anxiety, Stress and Coping. https://doi.org/10.1080/10615806.2020.1797695

[21] Beckmann, J., Czudaj, R. L., \& Arora, V. (2020). The relationship between oil prices and exchange rates: Revisiting theory and evidence. Energy Economics. https://doi.org/10.1016/j.eneco.2020.104772

[22] Boediono. (2017). Ekonomi Moneter. Seri Sinopsis Pengantar Ilmu Ekonomi No. 5.

[23] Boianovsky, M. (2020). Paul Samuelson's ways to macroeconomic dynamics. 
European Journal of the History of Economic Thought. https://doi.org/10.1080/09672567.2020.1767670

[24] Bonga-Bonga, L., \& Lebese, N. L. (2019). Rethinking The Current Inflation Target Range In South Africa. The Journal of Developing Areas. https://doi.org/10.1353/jda.2019.0018

[25] Brand, J., No, V., \& Thaha, A. F. (2020). DAMPAK COVID-19 TERHADAP UMKM DI INDONESIA A . PENDAHULUAN. Jurnal Brand.

[26] Cecchi, N. J., Monroe, D. C., Moscoso, W. X., Hicks, J. W., \& Reinkensmeyer, D. J. (2020). Effects of soccer ball inflation pressure and velocity on peak linear and rotational accelerations of ball-to-head impacts. Sports Engineering. https://doi.org/10.1007/s12283-020-00331-0

[27] Chabossou, A. F. C., Nonvide, G. M. A., Lokonon, B. O. K., Amegnaglo, C. J., \& Akpo, L. G. (2021). COVID-19 and the Performance of Exporting Companies in Benin. European Journal of Development Research. https://doi.org/10.1057/s41287021-00395-z

[28] Chaudhary, M. K., Ghimire, R. P., \& Ghimire, D. M. (2020). FOREIGN DIRECT INVESTMENT AND ITS COMMITMENT: IMPACT OF COVID-19 IN NEPAL WITH SOUTH ASIAN PERSPECTIVE. Journal of Developing Economies. https://doi.org/10.20473/jde.v5i2.21409

[29] Cho, D.-S., Moon, H.-C., \& Yin, W. (2016). Enhancing national competitiveness through national cooperation. Competitiveness Review. https://doi.org/10.1108/cr-052015-0036

[30] Cho, D. S., Moon, H. C., \& Yin, W. (2016). Enhancing national competitiveness through national cooperation: The case of South Korea and Dubai. Competitiveness Review. https://doi.org/10.1108/CR-05-2015-0036

[31] Cicih Ratnasih, (2016). Analisis Penggunaan Variabel Intervening Terhadap Variabel Endogen (Kasus Pada UMKM “X”). Jurnal Manajemen FEUB Volume 4 No. 2 Tahun 2016

[32] Dastgerdi, H. G. (2020). Inflation Theories and Inflation Persistence in Iran. Zagreb International Review of Economics and Business. https://doi.org/10.2478/zireb-20200011

[33] Dendawijaya, Lukman (2015). Manajemen Perbankan. Jakarta : Ghalia Indonesia

[34] Dylan Trotsek. (2017). Teori Investasi. Journal of Chemical Information and Modeling.

[35] Gaspar, J. M. (2020). Paul Krugman: contributions to Geography and Trade. Letters in Spatial and Resource Sciences. https://doi.org/10.1007/s12076-020-00247-0

[36] GOukm. (2016). Pengertian UKM \& UMKM? Bagaimana Usaha Kecil Menengah di Indonesia.

[37] Gunawan, C., \& Firdausy, C. M. (2019). Pengaruh PDB, Inflasi, Tingkat Suku Bunga dan Nilai Tukar Rupiah terhadap Indeks Harga Saham JAKPROP yang Terdaftar di Bursa Efek Indonesia. Jurnal Manajemen Bisnis Dan Kewirausahaan. https://doi.org/10.24912/jmbk.v1i1.4758

[38] Hartono, J. (2017). Teori portofolio dan analisis investasi (edisi Kesebelas). Yogyakarta: BPFE.

[39] Ibrahim, A. (2021). Pengertian Pembangunan menurut Para Ahli. Pengertiandefinisi.Com.

[40] Idris Muhammad. (2021). Apa Itu Inflasi: Pengertian, Penyebab, Dampak, dan Perhitungannya. 
[41] IN Pradani. (2016). TINJAUAN PUSTAKA: Tinjauan Umum tentang Bank dan Kredit Bermasalah. Reposity Ekuitas.Ac.Id.

[42] Indriani, M. (2016). Peran Tenaga Kerja Indonesia dalam Pembangunan Ekonomi. Gema Keadilan.

[43] İslam Altun, (2017). Determinants of The Export Performance of SMEs: Comparative Analysis of Türkish SMEs Exporting to Middle East and European Regions. International Journal of Business and Social Science Vol. 8, No. 3; March 2017

[44] Kandil, M., \& Dincer, N. N. (2011). A comparative analysis of exchange rate fluctuations and economic activity: The cases of Egypt and Turkey. In Exchange Rates: Policies, Effects and Fluctuations.

[45] Kartikasari, D. (2017). International Journal of Economics and Financial Issues The Effect of Export, Import and Investment to Economic Growth of Riau Islands Indonesia. International Journal of Economics and Financial Issues.

[46] Katua, N. T. (2014). The Role of SMEs in Employment Creation and Economic Growth in Selected Countries. International Journal of Education and Research.

[47] Keen, S. (2020). Emergent Macroeconomics: Deriving Minsky's Financial Instability Hypothesis Directly from Macroeconomic Definitions. Review of Political Economy. https://doi.org/10.1080/09538259.2020.1810887

[48] Khalid, H. A., \& Kalsom, A. W. (2014). Financing of small and medium enterprises (SMEs): Determinants of bank loan application. African Journal of Business Management. https://doi.org/10.5897/ajbm2013.7222

[49] Kharisma, R. M., \& Sopyan, I. (2017). Dissolution Rate Repairing of Simvastatin as A New Approach in Cocrystallization. Scholars Research Library.

[50] Kuncoro, M., \& Idris, A. N. (2015). MENGAPA TERJADI GROWTH WITHOUT DEVELOPMENT DI PROVINSI KALIMANTAN TIMUR? Jurnal Ekonomi Pembangunan: Kajian Masalah Ekonomi Dan Pembangunan. https://doi.org/10.23917/jep.v11i2.323

[51] Mahadika, I. N., Kalayci, S., \& Altun, N. (2017). Relationship between GDP, Foreign Direct Investment and Export Volume: Evidence from Indonesia. International Journal of Trade, Economics and Finance. https://doi.org/10.18178/ijtef.2017.8.1.538

[52] Maipita, I., \& Wahyudi, S. T. (2017). Income Distribution and Inequality in Indonesia: Study on Middle Class Household. Jurnal Ekonomi Pembangunan: Kajian Masalah Ekonomi Dan Pembangunan. https://doi.org/10.23917/jep.v18i1.3974

[53] Mankiw, N. G., \& Reis, R. (2018). Friedman's presidential address in the evolution of macroeconomic thought. In Journal of Economic Perspectives. https://doi.org/10.1257/jep.32.1.81

[54] Margareth, L., \& Simanjuntak, M. R. A. (2010). Pengaruh Produktivitas Tenaga Kerja Terhadap Kinerja Proyek Bangunan Tinggi Di DKI Jakarta. Konferensi Nesional Teknis Sipil.

[55] Mulyadi, A., Hardiani, \& Umiyati, E. (2018). Faktor-faktor yang mempengaruhi penyerapan tenaga kerja pada sektor industri kecil di Kabupaten Muaro Jambi. Jurnal Perdagangan Industri Dan Moneter.

[56] Mussardo, G. (2019). Pengertian Kredit dan Pembiayaan. Statistical Field Theor.

[57] Nagy, J., \& Jámbor, Z. (2018). Competitiveness in global trade: The case of the automobile industry. Economic Annals. https://doi.org/10.2298/EKA1818061N

[58] Pati, U. K. (2020). Indonesian Government Policy in Mitigating Economic Risks due to the Impact of the Covid-19 Outbreak. Journal of Law and Legal Reform. 
https://doi.org/10.15294/jllr.v1i4.39539

[59] Pindyck, R. S. (2017). The use and misuse of models for climate policy. Review of Environmental Economics and Policy. https://doi.org/10.1093/reep/rew012

[60] Porter, M. E. (2018). Competitive Strategy: Techniques for Analyzing Industries and Competitors.

[61] Pramudita, R. A., \& Yucha, N. (2020). Analisis Covid-19 Penghambat Ekspor-Impor dan Bisnis Antara Indonesia dan Cina. Journal Ecopreneur.

[62] Prastha, R. (2020). pengertian tenaga kerja. Https://Guruakuntansi.Co.Id/TenagaKerjal.

[63] Priewe, J. (2017). Review of exchange-rate theories in four leading economics textbooks. European Journal of Economics and Economic Policies: Intervention. https://doi.org/10.4337/ejeep.2017.01.04

[64] Purbasari, R. M. (2016). Karakteristik Bisnis Internasional. Karakteristik Bisnis Internasiona.

[65] Purusa, N. A., \& Istiqomah, N. (2018). Impact of FDI, COP, and Inflation to Export in Five ASEAN Countries. Jurnal Ekonomi Pembangunan: Kajian Masalah Ekonomi Dan Pembangunan. https://doi.org/10.23917/jep.v19i1.5832

[66] Purwanti, Endang. (2012). Pengaruh Karakteristik Wirausaha, Modal Usaha, Strategi Pemasaran Terhadap Perkembangan UMKM di Desa Dayaan dan Kalilondo Salatiga Vol. 5 No. 9, Juli 2012. STIE AMA Salatiga. 13-28 hal.

[67] Rajput, N., Rajput, A., Batra, G., \& Oberoi, S. (2012). Relationship of exports, Forex and MSMEs in India: An econometric study. Problems and Perspectives in Management.

[68] Rogoff, B. (2014). World views inpsychology: trait, interactional, organismic, and transactional perspectives. In D. Stokols \& I. Altman (Eds). Handbook of Environmental Psychology, Vol. 1. New York: Wiley, pp. 7-40.

[69] Rosita, R. (2020). PENGARUH PANDEMI COVID-19 TERHADAP UMKM DI INDONESIA. JURNAL LENTERA BISNIS. https://doi.org/10.34127/jrlab.v9i2.380

[70] A. Ross, Stephen, dkk. (2015). Pengantar Keuangan Perusahaan. Jakarta: Salemba Empat.

[71] Rukti Tanaya, D., \& Ekyawan, F. (2020). Empowerment Strategy on Micro, Small, and Medium Enterprises (MSMEs) during COVID-19 Pandemic in Indonesia: A Case Study of BRI Microfinance Center. In E3S Web of Conferences. https://doi.org/10.1051/e3sconf/202020203022

[72] Saefuloh, A. A. (2017). Perkembangan Ekonomi dan Kebijakan Makro Ekonomi. Berkas.Dpr.Go.Id.

[73] Sahoo, P., \& Ashwani. (2020). COVID-19 and Indian Economy: Impact on Growth, Manufacturing, Trade and MSME Sector. Global Business Review. https://doi.org/10.1177/0972150920945687

[74] Saini, B., \& Raghuveer Singh Rajpurohit. (2014). An Empirical Study on Export Financing (Awareness, Impact and Satisfaction) among Handicraft Export Firms in India. Pacific Business Review International.

[75] Sajou, D. M., Putri, K. M. T., \& Dwi, N. F. (2020). Peran Negara Atas Perlindungan Hukum Tenaga Kerja Indonesia Pada Masa Pandemi COVID-19. Jurnal Syntax Transformation.

[76] Saleh, M., \& Sumarsono, S. (2016). PERGESERAN SEKTOR EKONOMI DAN PENYERAPAN TENAGA KERJA DI JAWA TIMUR. Jurnal Kependudukan Indonesia. 
[77] Saturwa, H. N., Suharno, S., \& Ahmad, A. A. (2021). The impact of Covid-19 pandemic on MSMEs. Jurnal Ekonomi Dan Bisnis. https://doi.org/10.24914/jeb.v24i1.3905

[78] Sentosa, S. U., Ariusni, \& Triani, M. (2015). The Development Strategy of Small Scale Industries Crackers Sanjai to Increase Income and Employment Opportunities in Bukittinggi, Indonesia. Nternational Journal of Business and Social Science.

[79] Seyoum, B., \& Teshome, E. (2017). Major Transboundary Disease of Ruminants and their Economic Effect in Ethiopia. Type: Double Blind Peer Reviewed International Research Journal Publisher: Global Journals Inc.

[80] Shafi, M., Liu, J., \& Ren, W. (2020). Impact of COVID-19 pandemic on micro, small, and medium-sized Enterprises operating in Pakistan. Research in Globalization. https://doi.org/10.1016/j.resglo.2020.100018

[81] Sharma, P., \& Gounder, N. (2013). Obstacles to bank financing of micro and small enterprises: Empirical evidence from the Pacific with some policy implications. AsiaPacific Development Journal. https://doi.org/10.18356/baflef41-en

[82] Sugi Priharto. (2020). Perdagangan Internasional: Pengertian, Teori, Manfaat, dan Faktor Pendorongnya. Accurate.Id.

[83] Suhail Mohammad Ghouse, (2014). Export Competitiveness Of India: The Role Of MSMEs To Play. International Journal of Management Research \& Review Volume 4/Issue 11/Article No-6/1069-1084

[84] Sukirno, S. (2018). Ekonomi Pembangunan: Proses, Masalah, dan Dasar Kebijakan. e-conversion - Proposal for a Cluster of Excellence.

[85] Suryani, E. (2021). ANALISIS DAMPAK COVID-19 TERHADAP UMKM. Jurnal Inovasi Penelitian.

[86] Tandelilin, E. (2018). GAINS FROM INTERNATIONAL DIVERSIFICATION AND DOMESTIC PORTFOLIO IN EMERGING STOCKS MARKETS: PHILIPPINE AND INDONESIAN PERSPECTIVES. Gadjah Mada International Journal of Business. https://doi.org/10.22146/gamaijb.37900

[87] Tandjung, M. (2011). Aspek dan prosedur ekspor-impor. Jakarta: Salemba Empat.

[88] Thaha, A. F. (2020). Dampak Covid-19 Terhadap UMKM di Indonesia. Jurnal Lentera Bisnis.

[89] Thobarry, A. (2009). Analisis Pengaruh nilai tukar, suku bunga, laju inflasi dan pertumbuhan GDP terhadap indeks harga saham sektor properti (kajian empiris pada Bursa Efek Indonesia periode pengamatan tahun. Program Pascasarjana Universi-Tas Diponegoro. Semarang.

[90] Todaro, M. P., \& Smith, S. C. (2014). Economic Development, Twelfth edn. Pearson Addison Wesley, Boston.

[91] Tülüce, N. S., \& Doğan, İ. (2014). The Impact of Foreign Direct Investments on SMEs' Development. Procedia - Social and Behavioral Sciences. https://doi.org/10.1016/j.sbspro.2014.09.012

[92] van Marrewijk, C. (2011). Basic Exchange Rate Theories. SSRN Electronic Journal. https://doi.org/10.2139/ssrn.680403

[93] Wulandari, Ay. (2020). Pengaruh Motivasi Investasi Dan Pengetahuan Investasi Terhadap Minat Investasi Mahasiswa Di Pasar Modal. Journal of Chemical Information and Modeling.

[94] Yolanda. (2017a). Impacts of export development on unemployment in Indonesia. European Research Studies Journal. https://doi.org/10.35808/ersj/743

[95] Yolanda, Y. (2017b). Analysis of factors affecting inflation and its impact on human 
development index and poverty in Indonesia. European Research Studies Journal. https://doi.org/10.35808/ersj/873

[96] Yusdja, Y. (2016). Tinjauan Teori Perdagangan Internasional dan Keunggulan Kooperatif. Forum Penelitian Agro Ekonomi. https://doi.org/10.21082/fae.v22n2.2004.126-141

[97] Zahroh, S., Pontoh, R., Hidayat, Y., Jiwani, N. M., Supartini, E., \& Sukono. (2020). Indonesian rupiah exchange rate in facing COVID-19 (A time series-machine learning approach). Journal of Advanced Research in Dynamical and Control Systems. https://doi.org/10.5373/JARDCS/V12I6/S20201103

[98] Zimon, G., \& Tarighi, H. (2021). Effects of the COVID-19 Global Crisis on the Working Capital Management Policy: Evidence from Poland. Journal of Risk and Financial Management. https://doi.org/10.3390/jrfm14040169 